\title{
Chemotherapeutic Effect of CD147 Antibody-labeled Micelles Encapsulating Doxorubicin Conjugate Targeting CD147-Expressing Carcinoma Cells
}

\author{
TADASHI ASAKURA ${ }^{1}$, MASAYUKI YOKOYAMA ${ }^{2}$, KOICHI SHIRAISHI $^{2}$, \\ KATSUHIKO AOKI ${ }^{3}$ and KIYOSHI OHKAWA ${ }^{3}$ \\ ${ }^{1}$ Radioisotope Research Facilities, ${ }^{2}$ Medical Engineering Laboratory, \\ ${ }^{3}$ Department of Biochemistry, Jikei University School of Medicine, Tokyo, Japan
}

\begin{abstract}
Background: CD147 (basigin/emmprin) is expressed on the surface of carcinoma cells. Materials and Methods: For studying the efficacy of CD147-targeting medicine on CD147-expressing cells, we studied the effect of anti-CD147-labeled polymeric micelles (CD147ab micelles) that encapsulated a conjugate of doxorubicin with glutathione (GSH-DXR), with specific accumulation and cytotoxicity against CD147-expressing A431 human epidermoid carcinoma cells, Ishikawa human endometrial adenocarcinoma cells, and PC3 human prostate carcinoma cells. Results: By treatment of each cell type with CD147ab micelles for $1 \mathrm{~h}$, a specific accumulation of CD147ab micelles in CD147-expressing cells was observed. In addition, the cytotoxicity of GSH-DXRencapsulated micelles against each cell type was measured by treatment of the micelles for $1 \mathrm{~h}$. The cytotoxic effect of CD147ab micelles carrying GSH-DXR was 3- to 10-fold higher for these cells than that of micelles without GSH-DXR. Conclusion: These results suggest that GSH-DXR-encapsulated CD147ab micelles could serve as an effective drug delivery system to CD147-expressing carcinoma cells.
\end{abstract}

Conjugates of monoclonal antibodies with anticancer drugs have been studied for many years as a potential approach to delivering these agents more specifically to cancer cells (1). For example, rituximab, a monoclonal antibody targeting panB cell marker CD20, was the first monoclonal neutralizing

This article is freely accessible online.

Correspondence to: Tadashi Asakura, Ph.D., Radioisotope Research Facilities, Jikei University School of Medicine, 3-25-8 Nishishinbashi, Minato-ku, Tokyo 105-8461, Japan. Tel: +81 334331111, Fax: +81 334351922, e-mail: tad_asakura@jikei.ac.jp

Key Words: Emmprin/CD147, BSG, basigin, drug delivery system, block copolymer, polymeric micelle. antibody developed for treatment (2-5). In addition, drugmonoclonal antibody conjugates are currently being developed for the treatment of various types of solid tumor (6).

The extracellular matrix metalloproteinase inducer CD147 (also known as basigin or emmprin) up-regulates matrix metalloproteinase expression in the surrounding fibroblasts and endothelial cells and promotes the invasion of cancer cells. CD147 is a 55-kDa molecule localized on the surface of tumor cells $(7,8)$ and expression of CD147 has been frequently detected in human tumors cells (9). CD147 is expected to potentially serve as a target for antitumor therapy. We prepared CD147 antibody, a murine monoclonal antibody specific for human ovarian cancer, by immunizing mice with the human ovarian germ cell line JOHYC-2 (10). This $12 \mathrm{C} 3$ epitope was in the extracellular region (11).

We previously found that conjugates of doxorubicin (DXR) and glutathione (GSH) (GSH-DXR) prepared for the purpose of overcoming drug resistance strongly induced apoptosis in many cancer cells at lower concentration than DXR (12-16).

Previous drug carriers were micro-(or nano)-particles, liposomes and non-micelle-forming polymeric carriers. Polymeric micelles have been developed as a new type of drug carrier. The study of polymeric micelle drug carriers started in the 1980s (17-19), and these carrier systems were recognized as one of the most potent drug carrier types in the 1990s (20-25). Then, in the 2000s, several significant related clinical trials (26-33) were carried out, while more and more research development projects were conducted.

A polymeric micelle is a macromolecular assembly composed of an inner core and an outer shell. The polymeric micelles can have a spherical or a cylindrical shape, depending on the chemical structure and chain length of the macromolecules. For the purpose of drug targeting, most polymeric micelle studies have dealt with the spherical shape, whereas a very limited number of the filamentous shape systems have been studied (34, 35). A spherical polymeric micelle structure is formed from block copolymers or graft copolymers (36). 
In this study, we examined the therapeutic effect of CD147 antibody-carrying (CD147ab) micelles for the treatment of several cancer cell lines. In addition, CD147ab micelles encapsulating GSH-DXR were also tested for specific cytotoxicity against carcinoma cells.

\section{Materials and Methods}

Materials. DXR was obtained from Kyowa Hakko Kogyo (Tokyo, Japan). Anti-mouse IgG-alkaline phosphatase conjugate, GSH, 3(4,5-dimethylthiazol-2-yl)-2,5-diphenyl tetrazorium bromide (MTT), 5-bromo-4-chloro-3-indolyl phosphate and nitro blue tetrazolium tablet (BCIP/NBT), and plasmid of small/short hairpin RNA (shRNA) for human CD147 were obtained from Sigma-Aldrich Japan (Tokyo, Japan). Dowex 50W x8 and glutaraldehyde were purchased from Nakarai Tesque (Kyoto, Japan). All other chemicals were of analytical grade.

Cell lines. A431 human epidermoid carcinoma cell line, Ishikawa human endometrial adenocarcinoma cell line, and PC3 human prostate carcinoma cell line from Health Science Research Resources Bank (Tokyo, Japan) were cultured with RPMI 1640 containing $10 \%$ heat-inactivated fetal bovine serum (growth medium) under conventional conditions $\left(37^{\circ} \mathrm{C}, 5 \% \mathrm{CO}_{2}\right)$.

Knockdown of CD147 expression in PC3 cells. Plasmid of shRNA for human CD147 was transfected into PC3 cells using the FuGENE 6 transfection reagent (Promega, Tokyo, Japan). The transfectants were selected by treatment with puromycin. A permanent CD147knockdown clone (PC3/KD) was obtained.

Conjugation of DXR with GSH. GSH-DXR was prepared as described previously (13-16). In brief, the combination of $1 \mathrm{mg}$ each of GSH and DXR in $0.15 \mathrm{M} \mathrm{NaCl}$ containing $0.1 \%$ glutaraldehyde was incubated at room temperature for $30 \mathrm{~min}$. After incubation, GSH-DXR was purified using Dowex $50 \mathrm{~W} \times 8\left(\mathrm{H}^{+}\right.$form). The concentration of DXR was measured by absorbance at $495 \mathrm{~nm}$.

Preparation of immuno CD147ab micelles. Immuno CD147ab micelles were prepared by GSH-DXR incorporation process followed by conjugation with both CD147ab and green fluorescent protein (GFP). Poly(ethylene glycol)- $\beta$-poly(DXR-conjugated aspartic acid) $\{$ PEG- $\beta-P[$ Asp (DXR) $]\}$ block copolymer was the starting material (20-22). The molecular weight of the polyethylene glycol polymer was $1.20 \times 10^{4}$, and the average number of aspartic acid units was 18.4. DXR molecules were conjugated to $67.7 \%$ aspartic acid units. For the antibody and GFP conjugation, an aldehyde-terminated block copolymer, $\mathrm{CHO}-$ $\{\mathrm{PEG}-\beta-\mathrm{P}[\mathrm{Asp}(\mathrm{DXR})]\}$ was used. In this CHO-terminated block polymer, the molecular weight of the poly(ethylene glycol) polymer was $1.20 \times 10^{4}$, and the average number of aspartic acid units was 18.6. DXR molecules were conjugated to $47.8 \%$ aspartic acid units. Murine IgG micelles were prepared using mouse IgG instead of CD147ab.

Incorporation of GSH-DXR. Owing to hydrophobic interactions between the chemically conjugated DXR moiety and GSH-DXR molecules, GSH-DXR was physically incorporated into polymeric micelles formed from PEG- $\beta$-P[Asp(DXR)] and CHO-PEG- $\beta$ -

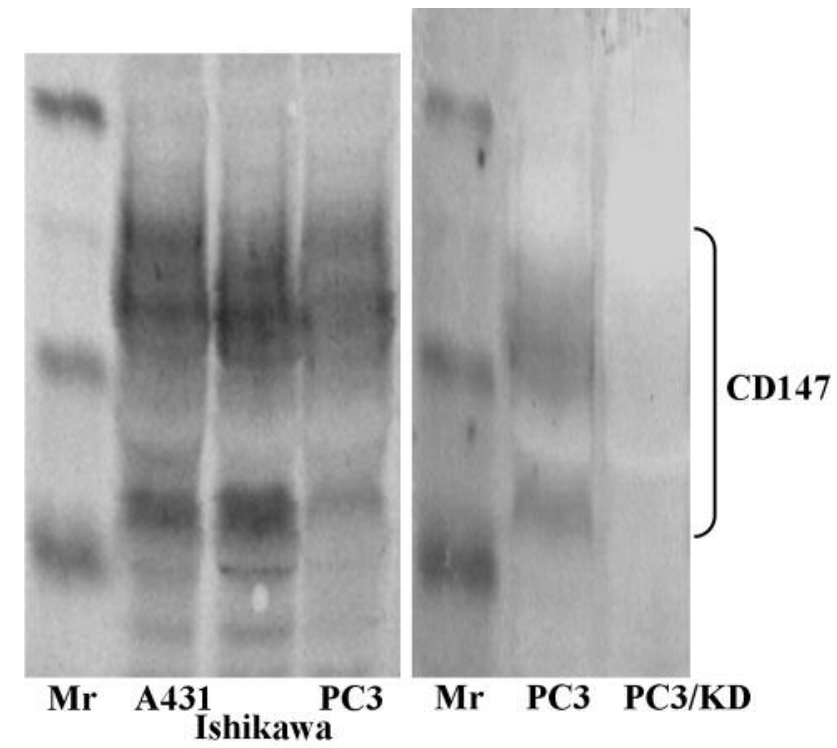

Figure 1. Expression of CD147 in A431, Ishikawa, PC3 and CD147knockdown PC3 (PC3/KD) cells detected by western blot analysis. Several bands of CD147 by binding of sugar chains were observed. Nevertheless, expression was not detected in PC3/KD. Mr, Protein marker.

$\mathrm{P}[\mathrm{Asp}(\mathrm{DXR})]$ using the dialysis technique. PEG- $\beta-\mathrm{P}[\mathrm{Asp}(\mathrm{DXR})]$, CHO-PEG- $\beta$-P[Asp(DXR)], and GSH-DXR were added to a solvent comprising water and $\mathrm{N}, \mathrm{N}$-dimethylformamide and dialyzed against water. The molar ratio of CHO-PEG- $\beta$ P[Asp(DXR)]: PEG- $\beta$-P[Asp(DXR)] was 1:9. After dialysis, the obtained micelles were purified by gel-filtration chromatography using Sephacryl S-300 with water as the eluent. The amount of GSH-DXR incorporated was measured by determining the absorption at $485 \mathrm{~nm}$, based on the assumption that absorption at $485 \mathrm{~nm}$ was the sum of absorption of the polymer-bound-DXR and the physically bound GSH-DXR.

CD147ab and GFP conjugation: The GSH-DXR-incorporated micelles thus obtained were mixed with both CD147ab and GFP at a molar ratio of 23:1:0.5 in $0.2 \mathrm{M}$ Tris- $\mathrm{HCl}$ buffer at $\mathrm{pH} 6.5$, and the solution stirred at room temperature for $24 \mathrm{~h}$. The reaction mixture was then purified by gel-filtration chromatography using Sephacryl S-300 in water for removal of unconjugated antibody. Complete removal of the unconjugated antibody and GFP was confirmed by gel-permeation chromatography using a TSK gel 4000PWXL-equipped HPLC system (Tosoh Corporation, Tokyo, Japan). The reaction ratio of the antibody molecule was found to be $52 \%$ upon calculation of the decrease in the antibody's peak area (refractive index) in the HPLC graphs obtained after and before the conjugation reaction.

Western blot analysis. CD147 in cells extracted with $1 \%$ Triton X100 was separated by sodium dodecyl sulfate-polyacrylamide gel electrophoresis (10\% acrylamide) and analyzed by western blot using $1 \mu \mathrm{g} / \mathrm{ml}$ of CD147ab (12C3) as the primary antibody and $1 \mu \mathrm{g} / \mathrm{ml}$ of alkaline phosphatase-labeled anti-mouse $\operatorname{IgG}$ as the secondary antibody, and this amount was assayed semi-quantification. 


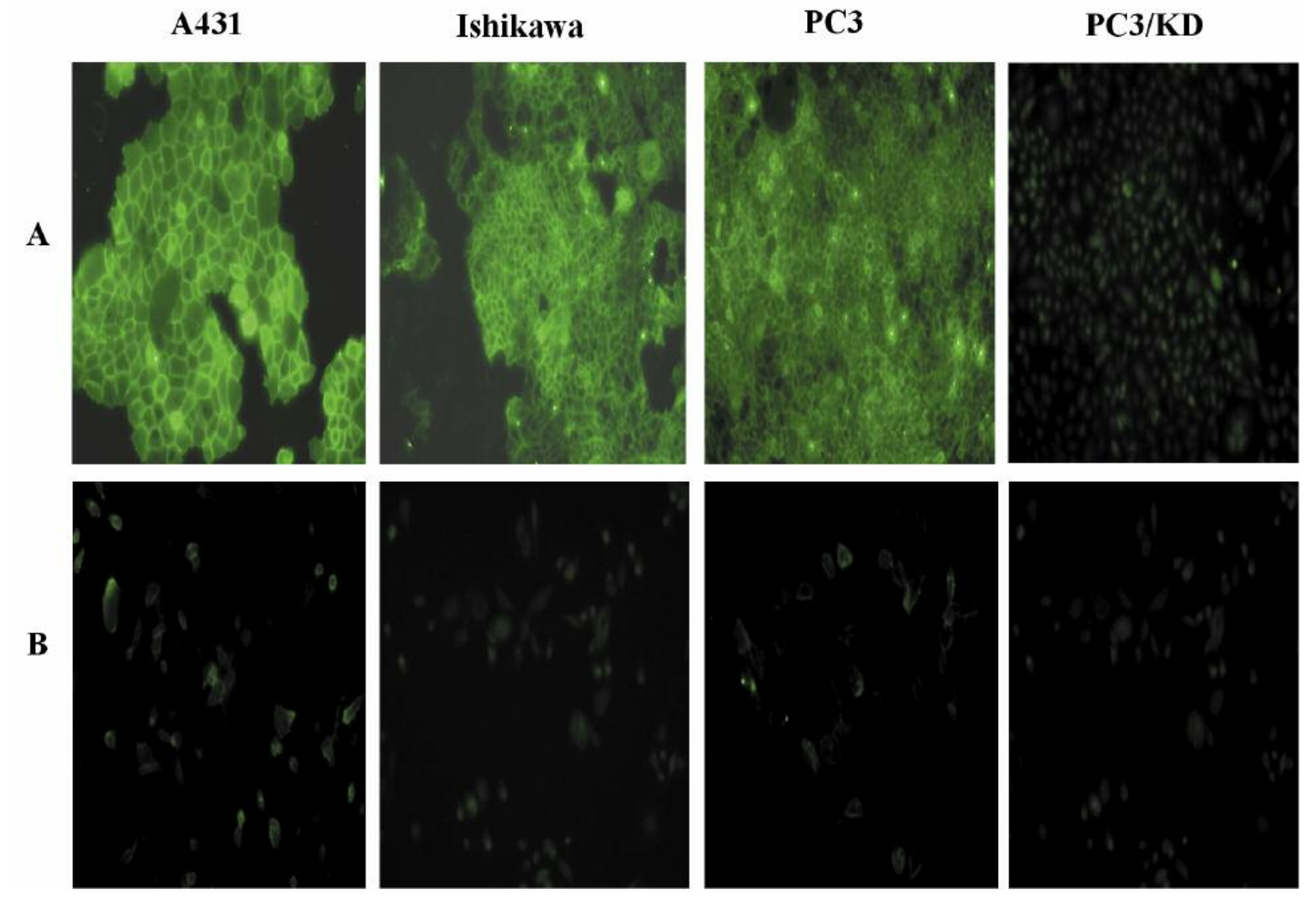

Figure 2. Accumulation of a conjugate of doxorubicin with glutathione (GSH-DXR)-encapsulating CD147ab-and green fluorescent protein (GFP)double-labeled micelles (GSH-DXR-CD147ab/GFP micelles) in A431, Ishikawa, PC3 and CD147-knockdown PC (PC3/KD) cells. Treatment of these cells with GSH-DXR-CD147ab/GFP micelles for $1 \mathrm{~h}(\mathrm{~A})$, and with the GSH-DXR-CD147ab/GFP micelles and excess CD147ab (B). Specific accumulation of GSH-DXR-CD147ab/GFP micelles by CD147-expressing cells was observed. Accumulation of the micelles after $1 \mathrm{~h}$ exposure in each cell line was observed by fluorescent microscopy.

Immunoreaction of CD147-labeled micelles. A431, Ishikawa and PC3 cells were incubated with GSH-DXR-encapsulated CD147aband GFP-double-labeled micelles (GSH-DXR-CD147ab/GFP micelles) for $1 \mathrm{~h}$ and washed with phosphate-buffered saline. The fluorescence of GFP was detected by fluorescent microscopy, and these amounts were assayed semi-quantification.

Cytotoxicity of GSH-DXR-CD147ab/GFP micelles. The cytotoxicity of GSH-DXR-CD147ab/GFP micelles against A431, Ishikawa, PC3 and PC3/KD cells after a 1-h treatment was measured after $96 \mathrm{~h}$ by an MTT assay (12-16). The cell death rate due to GSH-DXR-CD147ab/GFP micelles and GSH-DXRencapsulating murine IgG/GFP micelles $(0.1 \mu \mathrm{M}$ GSH-DXR) was expressed relative to that induced by $\mathrm{CD} 147 \mathrm{ab} / \mathrm{GFP}$ micelles and mouse IgG/GFP micelles without GSH-DXR, respectively (100\% survival rate).

Protein determination. Protein concentration was assayed by a BioRad protein assay kit (Bio-Rad Corporation, Tokyo, Japan) using bovine serum albumin (Wako, Japan) as the standard.

\section{Results}

Expression of CD147 in A431, Ishikawa, PC3 and PC3/KD cells by western blot analysis. The expression of CD147 (55-kDa) in A431, Ishikawa and PC3 cells at the protein level was observed by western blot analysis using $12 \mathrm{C} 3$ as a primary CD147 antibody (Figure 1). Several bands of CD147 by binding of sugar chains were observed. Nevertheless, expression was not detected in PC3/KD cells.

Accumulation of CD147ab/GFP micelles in A431, Ishikawa, PC3 and PC3/KD cells. After treatment of A431 cells with GSH-DXR-encapsulating CD147ab- and GFP-doublelabeled micelles (GSH-DXR-CD147ab/GFP micelles) for $1 \mathrm{~h}$, we found that the GSH-DXR-CD147ab/GFP micelles accumulated in the cells (Figure 2A). Moreover, co-treatment 


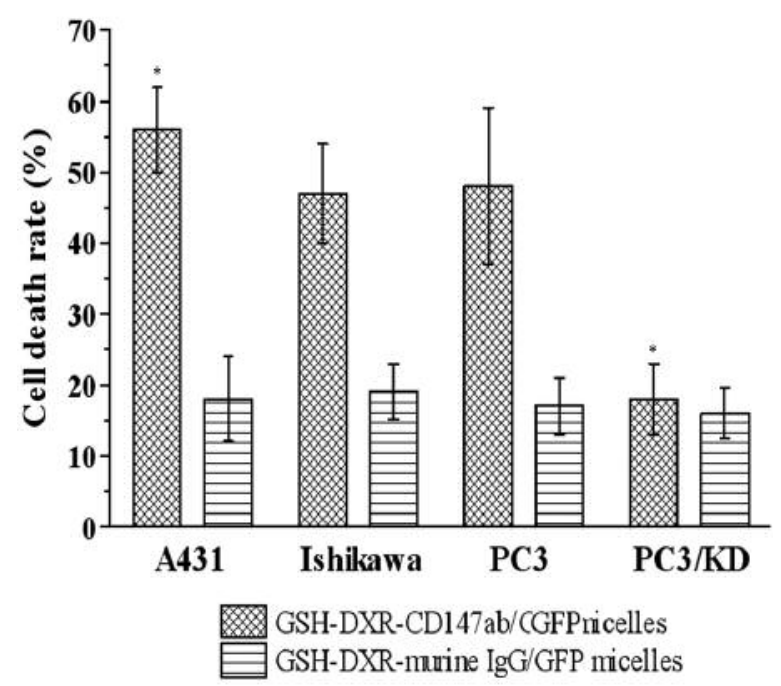

Figure 3. Cytotoxicity against A431, Ishikawa, PC3 and CD147knockdown PC3 $(P C 3 / K D)$ cells of conjugate of doxorubicin with glutathione (GSH-DXR)-encapsulating CD147ab-and green fluorescent protein (GFP)-double-labeled micelles (GSH-DXR-CD147ab/GFP micelles) (0.1 $\mu M$ of GSH-DXR, for 1-h exposure) and GSH-DXRmurine IgG/GFP micelles ( $0.1 \mu M$ GSH-DXR, for 1-h exposure). MTT assay was carried out 96 h after treatment. The cell death rate was expressed relative to that of CD147ab/GFP micelles and murine IgG/GFP micelles without GSH-DXR (100\% survival). Data are the mean $\pm S D$ (three independent experiments, ${ }^{*} p<0.01$ ).

of the cells with GSH-DXR-CD147ab/GFP micelles and excess CD147ab (100 $\mu \mathrm{g} / \mathrm{ml})$ competitively suppressed the accumulation of the micelles (Figure 2B). Therefore, specific accumulation of GSH-DXR-CD147ab/GFP micelles was observed on CD147-expressing cells. However, accumulation was not observed in PC3/KD cells (Figure 2).

Cytotoxicity of GSH-DXR-CD147ab/GFP micelles against A431, Ishikawa, PC3 and PC3/KD cells. Cytotoxicity of GSH-DXR-CD147ab/GFP micelles against A431, Ishikawa, PC 3 and PC $3 / \mathrm{KD}$ cells treated for $1 \mathrm{~h}$ was measured after $96 \mathrm{~h}$ (Figure 3). The cell death rate for GSH-DXRCD147ab/GFP micelles (0.1 $\mu \mathrm{M}$ GSH-DXR) and control GSH-DXR-murine IgG/GFP micelles (0.1 $\mu \mathrm{M}$ GSH-DXR) was found to be $56 \%$ and $18 \%$ for A431, $47 \%$ and $20 \%$ for Ishikawa, $48 \%$ and $17 \%$ for PC3, and $18 \%$ and $16 \%$ for $\mathrm{PC} 3 / \mathrm{KD}$, respectively (Figure 3 ). It is suggested that the cytotoxicity of GSH-DXR-CD147ab/GFP micelles is dependent on the expression of CD147.

\section{Discussion}

By western blot analysis, high levels of CD147 protein expression were observed in various carcinoma cells but not in normal tissues $(10,11)$. Considering that the anticancer drug was effective at an early stage, it was expected that CD147 could have sufficient ability in targeted therapy.

Various physiological processes, such as proliferation and differentiation of epithelial cells (37-39), fertilization (40), differentiation and activation of immune cells (41-43), integrin-mediated adhesion of myocytes of the left heart ventricle to basement membrane components (44), selective transport processes in endothelial cells to maintain bloodbrain barrier function (45), erythrocyte maturation (46) and wound healing (47) might potentially be influenced by antiCD147 therapy (9). Thus, potential side-effects of CD147targeted conjugate therapy should be carefully evaluated.

We previously demonstrated that GSH-DXR exhibited potent cytotoxicity compared to DXR (14-16). The 50\% growth-inhibitory concentrations of DXR and GSH-DXR for rat ascites hepatoma AH66 cells were $300 \mathrm{nM}$ and $5 \mathrm{nM}$, respectively. The effect of GSH-DXR delivery to chemotherapy targets was examined using CD147ab/GFP micelles. CD147ab/GFP micelles specifically accumulated in CD147-expressing cells but not in CD147-deficient PC3/KD cells (Figure 2). Moreover, GSH-DXR-encapsulated CD147ab/GFP micelles exhibited a potent cytotoxicity against CD147-expressing cells (Figure 3). No cytocidal effect was observed for CD147ab alone, and the cell death rate of CD147ab (100 $\mu \mathrm{g} / \mathrm{ml})$ was $3 \%$ or less in all cells used (data not shown). We also demonstrated in previous work that the effect of GSH-DXR was reversed in multidrugresistant cells in which AH66/DR cells overexpressed Pglycoprotein and showed resistance to $10 \mu \mathrm{M}$ DXR (12-14). Therefore, it was expected that targeted chemotherapy of GSH-DXR would be effective for both drug-sensitive and drug-resistant tumor cells.

In this study, encapsulation of GSH-DXR into aCD147ab/GFP micelles was also examined and resulted in specific cytotoxicity against CD147-expressing carcinoma cells. We previously demonstrated that the micelles have an extremely long circulation time in blood (21) and could be expected to have a therapeutic effect in in vivo targeted chemotherapy.

Further studies will attempt to confirm the specific cytotoxicity using a three-dimensional cell culture system using a bio-reactor.

\section{References}

1 Trial PA, King HD and DubowchiK DM: Monoclonal antibody drug immunoconjugates for targeted treatment of cancer. Cancer Immunol Immunother 52: 328-337, 2003.

2 Anderson DR, Grillo-López A, Varns C, Chambers KS and Hanna N: Targeted anti-cancer therapy using rituximab, a chimeric anti-CD20 antibody (IDEC-C2B8) in the treatment of non-Hodgkin's B-cell lymphoma. Biochem Soc Trans 25: 705708, 1997. 
3 Maloney DG, Grillo-López AJ, White CA, Bodkin D, Schilder RJ, Neidhart JA, Janakiraman N, Foon KA, Liles TM, Dallaire BK, Wey K, Royston I, Davis T and Levy R: IDEC-C2B8 (Rituximab) anti-CD20 monoclonal antibody therapy in patients with relapsed low-grade non-Hodgkin's lymphoma. Blood 90: 2188-2195, 1997.

4 Maloney DG, Grillo-López AJ, Bodkin DJ, White CA, Liles TM, Royston I, Varns C, Rosenberg J and Levy R: IDEC-C2B8: results of a phase I multiple-dose trial in patients with relapsed non-Hodgkin's lymphoma. J Clin Oncol 15: 3266-3274, 1997.

5 Witziq TE, White CA, Wiseman GA, Gordon LI, Emmanouilides C, Raubitschek A, Janakiraman N, Gutheil J, Schilder RJ, Spies S, Silverman DH, Parker E and Grillo-López AJ: Phase I/II trial of IDEC-Y2B8 radioimmunotherapy for treatment of relapsed or refractory $\mathrm{CD} 20(+)$ B-cell nonHodgkin's lymphoma. J Clin Oncol 17: 3793-3803, 1999.

6 Griffiths GL, Mattes MJ, Stein R, Govindan SV, Horak ID, Hansen HJ and Goldenberg DM: Cure of SCID mice bearing human Blymphoma xenografts by an anti-CD74 antibody-anthracycline drug conjugate. Clin Cancer Res 9: 6567-6571, 2003.

7 Yang L, Zucker S and Toole BP: Roles of multifunctional glycoprotein, emmprin (basigin; CD147), in tumour progression. Thromb Haemost 93: 199-204, 2005.

8 Tang Y, Nakada MT, Kesavan P, McCabe F, Millar H, Rafferty P, Bugelski P and Yan L: Extracellular matrix metalloproteinase inducer stimulates tumor angiogenesis by elevating vascular endothelial cell growth factor and matrix metalloproteinases. Cancer Res 65: 3193-3199, 2005.

9 Riethdorf S, Reimers N, Assmann V, Kornfeld JW, Terracciano L, Sauter G and Pantel K: High incidence of EMMPRIN expression in human tumors. Int J Cancer 119: 1800-1810, 2006

10 Yamada K, Ohkawa K and Joh K: Monoclonal antibody, Mab $12 \mathrm{C} 3$, is a sensitive immunohistochemical marker of early malignant change in epithelial ovarian tumors. Am J Clin Pathol 103: 288-294, 1995.

11 Ishibashi Y, Matsumoto T, Niwa M, Suzuki Y, Omura N, Hanyu N, Nakada K, Yanaga K, Yamada K, Ohkawa K, Kawakami M and Urashima M: CD147 and matrix metalloproteinase-2 protein expression as significant prognostic factors in esophageal squamous cell carcinoma. Cancer 101: 1994-2000, 2004.

12 Takahashi N, Asakura $\mathrm{T}$ and Ohkawa K: Pharmacokinetic analysis of protein-conjugated doxorubicin (DXR) and its degraded adducts in DXR-sensitive and -resistant rat hepatoma cells. Anti-Cancer Drugs 7: 687-696, 1996.

13 Asakura T, Takahashi N, Takada K, Inoue T and Ohkawa K: Drug conjugate of doxorubicin with glutathione is a potent reverser of multidrug resistance in rat hepatoma cells. AntiCancer Drugs 8: 199-203, 1997.

14 Asakura T, Sawai T, Hashidume Y, Ohkawa Y, Yokoyama S and Ohkawa K: Caspase-3 activation during doxorubicin conjugated with glutathione-mediated apoptosis. Br J Cancer 80: 711-715, 1999.

15 Asakura T, Ohkawa K, Takahashi N, Takada K, Inoue T and Yokoyama S: Glutathione-doxorubicin conjugate expresses potent cytotoxicity by a suppression of glutathione S-transferase activity: Comparison between doxorubicin-sensitive and -resistant rat hepatoma cells. Br J Cancer 76: 1333-1337, 1997.

16 Asakura T, Hashizume Y, Tashiro K, Searashi Y, Ohkawa K, Nishihira J, Sakai M and Shibasaki T: Suppression of GST-P by treatment with glutathione-doxorubicin conjugate induces potent apoptosis in rat hepatoma cells. Int J Cancer 94: 171-177, 2001
17 Pratten MK, Lloyd JB and Ringsdorf H: Micelle-forming block copolymers: pinocytosis by macrophages and interaction with model membranes. Macromol Chem 186: 725-733, 1985.

18 Yokoyama M, Inoue S and Sakurai Y: Molecular design for missile drug: synthesis of adriamycin conjugated with IgG using poly(ethylene glycol)-poly (aspartic acid) block copolymer as intermediate carrier. Makromol Chem 190: 2041-2054, 1989.

19 Kabanov AV, Chekhonin VP, Alakhov VYu, Batrakova EV, Lebedev AS, Melik-Nubarov NS, Arzhakov SA, Levashov AV, Morozov GV, Severin ES and Kabanov VA: The neuroleptic activity of haloperidol increases after its solubilization in surfactant micelles: Micelles as microcontainers for drug targeting. FEBS Lett 258: 343-345, 1989.

20 Yokoyama M, Okano T, Sakurai Y, Ekimoto H, Shibazaki C and Kataoka K: Toxicity and antitumor activity against solid tumors of micelle-forming polymeric drug and its extremely long circulation in blood. Cancer Res 51: 3229-3236, 1991.

21 Yokoyama M, Okano T, Sakurai Y and Kataoka K: Improved synthesis of doxorubicin-conjugated poly(ethylene oxide)poly(aspartic acid) block copolymer and formation of unimodal micellar structure with controlled amount of physically entrapped doxrubcin. J Control Release 32: 269-277, 1994.

22 Yokoyama M, Okano T, Sakurai Y, Fukushima S, Okamoto K and Kataoka K: Selective delivery of adriamycin to a solid tumor using a polymeric micelle carrier system. J Drug Targeting 7: 171-186, 1999.

23 Batrakova EV, Dorodnych TY, Klinskii EY, Kliushnenkova EN, Shemchukova OB, Goncharova ON, Arjakov SA, Alakhov VY and Kabanov AV: Anthracycline antibiotics non-covalently incorporated into the block copolymer micelles: in vivo evaluation of anti-cancer activity. Br J Cancer 74: 1545-1552, 1996.

24 Inoue T, Chen G, Nakamae K and Hoffman AS: An AB block copolymer of oligo(methyl methacrylate) and poly(acrylic acid) for micellar delivery of hydrophobic drugs. J Control Release 51: 221-229, 1998.

25 Zhang X, Burt HM, Von Hoff D, Dexter D, Mangold G, Degen D, Oktaba AM and Hunter WL: An investigation of the antitumor activity and biodistribution of polymeric micellar paclitaxel. Cancer Chemother Pharmacol 40: 81-86, 1997.

26 Matsumura $\mathrm{Y}$ and Kataoka K: Preclinical and clinical studies of anticancer agent-incorporating polymer micelles. Cancer Sci 100: 572-579, 2009.

27 Matsumura Y: Poly (amino acid) micelle nanocarriers in preclinical and clinical studies. Adv Drug Deliv Rev 60: 899914, 2008.

28 Matsumura Y, Hamaguchi T, Ura T, Muro K, Yamada Y, Shimada Y, Shirao K, Okusaka T, Ueno H, Ikeda $M$ and Watanabe N: Phase I clinical trial and pharmacokinetic evaluation of NK911, a micelle-encapsulated doxorubicin. Br J Cancer 91: 1775-1781, 2004.

29 Hamaguchi T, Kato K, Yasui H, Morizane C, Ikeda M, Ueno H, Muro K, Yamada Y, Okusaka T, Shirao K, Shimada Y, Nakahama $\mathrm{H}$ and Matsumura Y: A phase I and pharmacokinetic study of NK105, a paclitaxel-incorporating micellar nanoparticle formulation. Br J Cancer 97: 170-176, 2007.

30 Kim DW, Kim SY, Kim HK, Kim SW, Shin SW, Kim JS, Park K, Lee MY and Heo DS: Multicenter phase II trial of GenexolPM, a novel Cremophor-free, polymeric micelle formulation of paclitaxel, with cisplatin in patients with advanced non-smallcell lung cancer. Ann Oncol 18: 2009-2014, 2007. 
31 Lee KS, Chung HC, Im SA, Park YH, Kim CS, Kim SB, Rha SY, Lee MY and Ro J: Multicenter phase II trial of Genexol-PM, a Cremophor-free, polymeric micelle formulation of paclitaxel, in patients with metastatic breast cancer. Breast Cancer Res Treat 108: 241-250, 2008.

32 Park SR, Oh DY, Kim DW, Kim TY, Heo DS, Bang YJ, Kim NK, Kang WK, Kim HT, Im SA, Suh JH, Kim HK and Kim HK: A multi-center, late phase II clinical trial of Genexol (paclitaxel) and cisplatin for patients with advanced gastric cancer. Oncol Rep 12: 1059-1064, 2004.

33 Kim TY, Kim DW, Chung JY, Shin SG, Kim SC, Heo DS, Kim NK and Bang YJ: Phase I and pharmacokinetic study of Genexol-PM, a cremophor-free, polymeric micelle-formulated paclitaxel, in patients with advanced malignancies. Clin Cancer Res 10: 3708-3716, 2004.

34 Christian DA, Cai S, Garbuzenko OB, Harada T, Zajac AL, Minko $\mathrm{T}$ and Discher DE: Flexible filaments for in vivo imaging and delivery: persistent circulation of filomicelles opens the dosage window for sustained tumor shrinkage. Mol Pharm 6: 1343-1352, 2009.

35 Geng Y, Dalhaimer P, Cai S, Tsai R, Tewari M, Minko T and Discher DE: Shape effects of filaments versus spherical particles in flow and drug delivery. Nat Nanotechnol 2: 249-255, 2007.

36 Tuzar Z and Kratochvil P: Block and graft copolymer micelles in solution. Adv Colloid Interface Sci 6: 201-232, 1976.

37 DeCastro R, Zhang Y, Guo H, Kataoka H, Gordon MK, Toole Bp and Biswas G: Human keratinocytes express EMMPRIN, an extracellular matrix metalloproteinase inducer. J Invest Dermatol 106: 1260-1265, 1996.

38 Chen X, Kanekura T and Kanzaki T: Expression of Basigin in human fetal, infantile and adult skin and in basal cell carcinoma. J Cutan Pathol 28: 184-190, 2001.

39 Chen X, Kanekura T, Tsuyama S, Murata F and Kanzaki T: Ultrastructural localization of basigin in normal human epidermis. Histochem Cell Biol 115: 465-470, 2001.

40 Kuno N, Kadomatsu K, Fan QW, Hagihara M, Senda T, Mizutani S and Muramatsu T: Female sterility in mice lacking the basigin gene, which encodes a transmembrane glycoprotein belonging to the immunoglobulin superfamily. FEBS Lett 425 : 191-194, 1998.
41 Koch C, Staffler G, Huttinger R, Hilgert I, Prager E, Cerný J, Steinlein P, Majdic O, Horejsí V and Stockinger H: T cell activation-associated epitopes of CD147 in regulation of T cell response, and their definition by antibody affinity and antigen density. Int Immunol 11: 777-786, 1999.

42 Kirsch AH, Diaz LA Jr., Bonish B, Antony PA and Fox DA: The pattern of expression of CD147/neurothelin during human T-cell ontogeny as defined by the monoclonal antibody 8D6. Tissue Antigens 50: 147-152, 1997.

43 Zhu P, Ding J, Zhon J, Dong WJ, Fan CM and Chen ZN: Expression of CD147 on monocytes/macrophages in rheumatoid arthritis: its potential role in monocyte accumulation and matrix metalloproteinase production. Arthritis Res Ther 7: R1023R1033, 2005.

44 Coker ML, Doscher MA, Thomas CV, Galis ZS and Spinale FG: Matrix metalloproteinase synthesis and expression in isolated LV myocyte preparations. Am J Physiol 277: H777-H787, 1999.

45 Sameshima T, Nabeshima K, Tole BP, Inoue T, Yokogami K, Nakano S, Ohi T and Wakisaka S: Correlation of emmprin expression in vascular endothelial cells with blood-brain-barrier function: a study using magnetic resonance imaging enhanced by Gd-DTPA and immunohistochemistry in brain tumors. Virchows Arch 442: 577-584, 2003.

46 Coste I, Gauchat JF, Wilson A, Izui S, Jeannin P, Delneste Y, MacDonald HR, Bonnefoy JY and Renno T: Unavailability of CD147 leads to selective erythrocyte trapping in the spleen. Blood 97: 3984-3988, 2001.

47 Gabison EE, Mourah S, Steinfels E, Yan L, Hoang-Xuan T, Watsky MA, De Wever B, Calvo F, Mauviel A and Menashi S: Differential expression of extracellular metalloproteinase inducer (CD147) in normal and ulcerated corneas: role in epitheliostromal interactions and matrix metalloproteinase induction. Am J Pathol 166: 209-219, 2005.

Received December 6, 2017

Revised January 23, 2018

Accepted January 24, 2018 